\title{
Pengaruh Korelasi Data pada Peramalan Kelembaban Udara Menggunakan Adaptive Neuro Fuzzy Inference System (ANFIS)
}

\author{
Dinita Rahmalia $^{1^{*}}$, Arif Rohmatullah ${ }^{2}$ \\ 1,2 Program Studi Matematika Universitas Islam Darul Ulum, Lamongan \\ *Corresponding Author \\ E-mail: dinitarahmalia@gmail.ac.id
}

\begin{abstract}
Abstrak
Peramalan cuaca merupakan kegiatan yang penting untuk beberapa aktivitas. Dalam peramalan cuaca, terdapat beberapa komponen yang diamati seperti suhu udara, kelembaban udara, intensitas matahari, dan sebagainya. Berdasarkan penelitian sebelumnya, intensitas matahari dipengaruhi oleh salah satu komponen yaitu kelembaban udara sehingga pada penelitian ini akan dilakukan peramalan pada data kelembaban udara. Pada penelitian ini akan dilakukan peramalan pada data kelembaban udara meggunakan Adaptive Neuro Fuzzy Inference System (ANFIS). Dalam ANFIS terdapat beberapa parameter yang akan dioptimisasi yaitu premise parameter dan consequent parameter. ANFIS menggunakan metode hybrid dalam perhitungan. Terdapat dua bagian dari metode hybrid : alur maju dan alur mundur. Simulasi dilakukan pada tiga dataset dengan struktur yang berbeda. Berdasarkan hasil simulasi, hasil peramalan tergantung pada nilai korelasi. Semakin kuat nilai korelasi (korelasi mendekati 1) menghasilkan hasil peramalan yang lebih baik yang ditandai dengan nilai Root of Mean Square Error (RMSE) yang kecil.
\end{abstract}

Kata Kunci: Regresi, Korelasi, Adaptive Neuro Fuzzy Inference System, Metode Hybrid.

\begin{abstract}
Weather forecasting is important work for some activities. In weather forecasting, there are some components observed such as air temperature, humidity, sunlight intensity, and so on. Based on previous research, sunlight intensity is affected by humidity so that in this research, it will be applied forecasting on humidity data. In this research, forecasting on humidity data uses Adaptive Neuro Fuzzy Inference System (ANFIS). In ANFIS there are some parameters which will be optimized such as premise parameter and consequent parameter. ANFIS uses hybrid method in training. There are two parts of hybrid method: forward path and backward path. Simulations are done in three datasets with different structure. Based on simulation results, forecasting results depend on correlation value. Stronger correlation value (correlation approaches to 1) results better forecasting with small Root of Mean Square Error (RMSE).
\end{abstract}

Keywords: Regression, Correlation, Adaptive Neuro Fuzzy Inference System, Hybrid Method

\section{PENDAhUluan}

Peramalan cuaca adalah kegiatan yang penting karena akan digunakan untuk memprediksi cuaca yang akan datang berdasarkan beberapa faktor. Pada peramalan cuaca, terdapat beberapa komponen yang diperlukan seperti suhu udara, kelembaban udara, intensitas matahari, dan sebagainya. Berdasarkan data dari kementrian Energi dan Sumber Daya Mineral (ESDM), Indonesia merupakan salah satu negara dengan konsumsi bahan bakar minyak (BBM) terbesar. Namun pada saat ini beberapa masyarakat telah memanfaatkan energi matahari menggunakan sel surya untuk mengendalikan pemakaian bahan bakar minyak (BBM) di Indonesia. Berdasarkan penelitian sebelumnya, intensitas matahari dipengaruhi oleh salah satu komponen yaitu kelembaban udara (Rahmalia dan Herlambang, 2017) sehingga pada penelitian ini akan dilakukan peramalan pada data kelembaban udara. 
Pada penelitian sebelumnya, beberapa metode telah digunakan pada masalah estimasi dan peramalan yaitu metode eksak seperti least square, maximum likelihood (Walpole, 2012), metode heuristik (Rahmalia, 2018), neural network (Rahmalia dan Aini, 2018; Rahmalia dan Pradana, 2019), dan kalman filter (Herlambang dkk, 2018). Pada penelitian ini akan dilakukan peramalan pada data kelembaban udara meggunakan Adaptive Neuro Fuzzy Inference System (ANFIS). Karena hasil peramalan tergantung pada nilai korelasi data, maka pada penelitian ini juga meneliti tentang pengaruh korelasi data pada peramalan kelembaban udara (Han, 2012).

Aplikasi fuzzy logic telah banyak digunakan, misalkan untuk masalah pengelompokkan atau klasterisasi pada data (Rahmalia dan Herlambang, 2018) maupun peramalan dan estimasi pada data (Shing dan Jang, 1993; Suparta dan Alhasa, 2016). Adaptive Neuro Fuzzy Inference System (ANFIS) diperkenalkan oleh Jang pada tahun 1993. Algoritma ini digunakan karena algoritma Backpropagation yang dipakai untuk melatih parameter masih memberikan konvergensi yang lambat. Algoritma ANFIS menggunakan metode hybrid dalam optimisasi parameternya (Shing dan Jang, 1993; Suparta dan Alhasa, 2016). ANFIS menggunakan metode hybrid dalam perhitungan. Terdapat dua bagian dari metode hybrid yaitu alur maju dan alur mundur. Pada alur maju, sinyal bergerak maju dan consequent parameter dihitung dengan Least Square Estimator (LSE). Pada alur mundur, laju error bergerak mundur dan premise parameter diupdate dengan penurunan gradient (gradient descent).

Simulasi dilakukan pada tiga dataset dengan struktur yang berbeda berdasarkan nilai korelasi. Dari data yang digunakan, akan dihitung korelasi antara input dan output. Sebelum simulasi ANFIS dilakukan, partisi data ke dalam data training dan data testing. Setelah simulasi ANFIS dilakukan, hasil peramalan tergantung pada nilai korelasi antara input dan output. Semakin kuat nilai korelasi yaitu korelasi mendekati satu, menghasilkan hasil peramalan yang lebih optimal yang dapat dilihat dengan nilai Root of Mean Square Error (RMSE) yang kecil.

\section{STUDI LITERATUR}

\subsection{Korelasi Data}

Korelasi adalah hubungan linear antara dua variabel $x$ dengan $y$. Koefisien korelasi dapat dihitung berdasarkan persamaan (1). Nilai dari koefisien korelasi adalah antara $-1 \leq r \leq 1$. Jika korelasi bernilai +1 , maka hubungan dua variabel adalah sempurna dan berbanding positif. Sedangkan jika korelasi bernilai -1, maka hubungan dua varibel adalah sempurna dan berbanding negatif. Jika korelasi bernilai 0 , maka tidak ada hubungan antara dua variabel $x$ dengan $y$ (Walpole, 2012).

$$
r_{x y}=\frac{S_{x y}}{\sqrt{S_{x x} S_{y y}}}
$$

dengan:

$$
\begin{gathered}
S_{x y}=\frac{1}{n-1} \sum_{i=1}^{n}\left(x_{i}-\bar{x}\right)\left(y_{i}-\bar{y}\right) \\
S_{x x}=\frac{1}{n-1} \sum_{i=1}^{n}\left(x_{i}-\bar{x}\right)^{2}
\end{gathered}
$$




$$
S_{y y}=\frac{1}{n-1} \sum_{i=1}^{n}\left(y_{i}-\bar{y}\right)^{2}
$$

\subsection{Adaptive Neuro Fuzzy Inference System (ANFIS)}

Adaptive Neuro Fuzzy Inference System (ANFIS) diperkenalkan oleh Jang pada tahun 1993. Algoritma ini digunakan karena algoritma Backpropagation yang dipakai untuk melatih parameter masih memberikan konvergensi yang lambat. Algoritma ANFIS menggunakan metode hybrid dalam proses optimisasi parameternya (Shing dan Jang, 1993; Suparta dan Alhasa, 2016).

Pada ANFIS terdapat lima layer dengan diagram dapat dilihat pada Gambar 1.

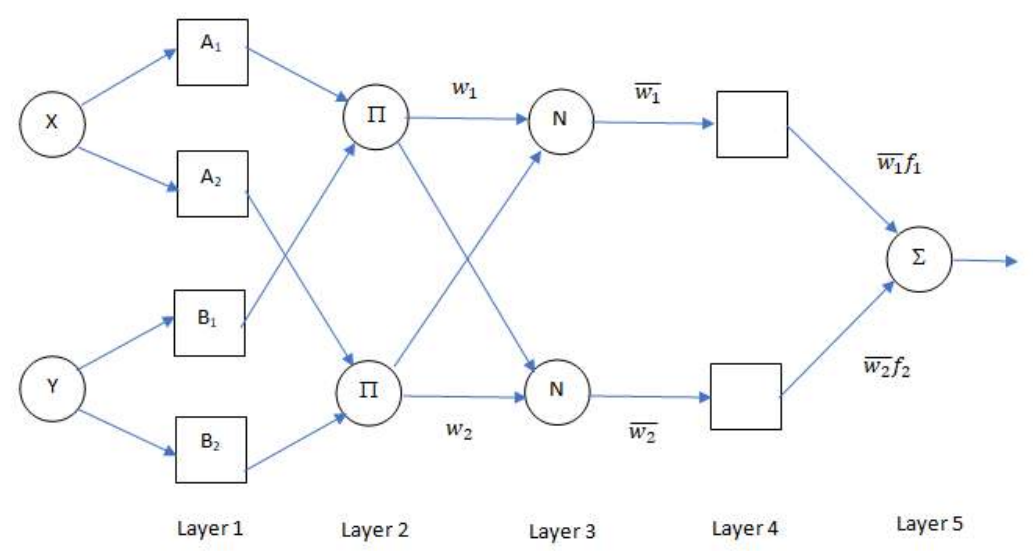

Gambar 1. Diagram Adaptive Neuro Fuzzy Inference System (ANFIS)

Misalkan terdapat dua input yaitu $x$ dan $y$, dan satu output $f$. Misalkan aturan fuzzy yang digunakan yaitu :

Aturan (Rule) 1 : Jika $x$ adalah $A_{1}$ dan $y$ adalah $B_{1}$ maka $f_{1}=p_{1} x+q_{1} y+r_{1}$

Aturan (Rule) 2 : Jika $x$ adalah $A_{2}$ dan $y$ adalah $B_{2}$ maka $f_{2}=p_{2} x+q_{2} y+r_{2}$

Dimana $A_{1}, A_{2}$ adalah fungsi keanggotaan untuk $x$ sedangkan $B_{1}, B_{2}$ adalah fungsi keanggotaan untuk $y$. Parameter $p_{1}, q_{1}, r_{1}$ dan $p_{2}, q_{2}, r_{2}$ adalah parameter akibat (consequent parameters) pada aturan 1 dan aturan 2 .

Layer 1. Setiap titik pada layer ini merupakan fungsi parameter sehingga output dari setiap titik adalah nilai derajat keanggotaan yang diberikan oleh input dari fungsi keanggotaan.

$$
\mathrm{O}_{1, i}=\mu_{A i}(x) i=1,2 \quad \mathrm{O}_{1, i}=\mu_{B i-2}(y) i=3,4
$$

Fungsi keanggotaan yang digunakan secara umum adalah fungsi keanggotaan Gaussian $\mu(x)=\exp \left(-\left(\frac{x-c}{a}\right)^{2}\right)$ atau fungsi keanggotaan generalized bell $\mu(x)=\frac{1}{1+\left(\frac{x-c}{a}\right)^{2 b}}$. Parameter $a, b, c$ dari fungsi keanggotaan tersebut adalah parameter sebab (premise parameter). 
Layer 2. Setiap titik pada layer merupakan adalah kekuatan untuk setiap aturan. Output titik ini adalah hasil perkalian dari sinyal yang datang ke dalam titik ini untuk dikirimkan ke titik berikutnya.

$$
\mathrm{O}_{2 i}=w_{i}=\mu_{A i}(x) * \mu_{B i}(y) i=1,2
$$

Layer 3. Setiap titik pada layer merupakan adalah perbandingan antara kekuatan aturan ke-i dan penjumlahan dari semua kekuatan aturan. Hasil perbandingan ini disebut sebagai kekuatan aturan normal.

$$
\mathrm{O}_{3 i}=\overline{w_{i}}=\frac{w_{i}}{\sum_{i} w_{i}} i=1,2
$$

Layer 4. Setiap titik pada layer merupakan adalah fungsi yang didefinisikan sebagai berikut :

$$
\mathrm{O}_{4 i}=\overline{w_{i}} f_{i}=\overline{w_{i}}\left(p_{i} x+q_{i} y+r_{i}\right) i=1,2
$$

Layer 5. Titik pada layer merupakan adalah penjumlahan dari setiap titik pada layer 4.

$$
\mathrm{O}_{5}=\sum_{i} \overline{w_{i}} f_{i}
$$

\subsection{Metode Hybrid}

Metode hybrid diperkenalkan oleh Jang pada tahun 1993 untuk melatih consequent parameter dan premise parameter. Terdapat dua bagian dari metode hybrid yaitu alur maju dan alur mundur. Pada alur maju, sinyal bergerak maju sampai layer 4 dan consequent parameter dihitung dengan Least Square Estimator (LSE). Pada alur mundur, laju error bergerak mundur dan premise parameter diupdate dengan penurunan gradient (gradient descent). Satu iterasi dari metode hybrid disebut epoch. Metode hybrid mengkombinasikan LSE dan penurunan gradient supaya dapat memberikan laju konvergensi yang lebih cepat daripada Backpropagation (Shing dan Jang, 1993; Suparta dan Alhasa, 2016).

\section{a. Optimisasi pada Premise Parameter}

Premise parameter $a, b, c$ dapat dilatih menggunakan Backpropagation dan penurunan gradient (gradient descent) sebagai berikut: Misalkan jaringan memiliki $L$ layer dan pada layer ke $k$ memiliki $\#(k)$ titik, sehingga titik $i$ pada layer ke $k$ adalah $(k, i)$ dengan titik output adalah $O_{i}^{k}$. Misalkan data training memiliki jumlah $p$, sehingga jumlah kuadrat error $E_{p}$ adalah:

$$
E_{p}=\sum_{m=1}^{\#(L)}\left(T_{m, p}-O_{m, p}^{L}\right)^{2}
$$


Dengan $T_{m, p}$ adalah nilai target komponen ke $m$ dari data ke $p$ dan $O_{m, p}^{L}$ adalah output komponen ke $m$ pada layer $L$ dari data ke $p$. Seluruh pengukuran untuk $N$ data training dapat dihitung dengan $E=\sum_{p=1}^{N} E_{p}$

Setelah nilai $E_{p}$ ditentukan, hitung gradient descent pada layer ke $L$

$$
\frac{\partial E_{p}}{\partial O_{i, p}^{L}}=-2\left(T_{i, p}-O_{i, p}^{L}\right)
$$

Pada titik $(k, i)$ secara umum dapat dihitung menggunakan aturan rantai persamaan 12.

$$
\frac{\partial E_{p}}{\partial O_{i, p}^{k}}=\sum_{m=1}^{\#(k+1)} \frac{\partial E_{p}}{\partial O_{m, p}^{k+1}} \cdot \frac{\partial O_{m, p}^{k+1}}{\partial O_{i, p}^{k}}
$$

Untuk setiap $1 \leq i \leq \#(k)$ dengan $1 \leq k \leq L-1$

Jika $\alpha$ adalah premise parameter dari jaringan, maka aturan rantainya seperti persamaan 13, dengan $S$ adalah himpunan titik yang outputnya tergantung pada $\alpha$.

$$
\frac{\partial E_{p}}{\partial \alpha}=\sum_{O^{*} \in S} \frac{\partial E_{p}}{\partial O^{*}} \cdot \frac{\partial O^{*}}{\partial \alpha}
$$

Keseluruhan nilai error untuk $N$ data training dapat dihitung menggunakan persamaan 14 .

$$
\frac{\partial E}{\partial \alpha}=\sum_{p=1}^{N} \frac{\partial E_{p}}{\partial \alpha}
$$

Update premise parameter menggunakan persamaan 15 dan persamaan 16.

$$
\begin{gathered}
\Delta \alpha=-\eta \frac{\partial E}{\partial \alpha} \\
\alpha_{\text {new }}=\alpha_{\text {old }}-\Delta \alpha=\alpha_{\text {old }}-\left(-\eta \frac{\partial E}{\partial \alpha}\right)
\end{gathered}
$$

dengan $\eta$ adalah learning rate.

\section{b. Optimisasi pada Consequent Parameter}

Optimisasi pada consequent parameter adalah menggunakan Least Square Estimation (LSE). Misalkan kombinasi linear dari output adalah: 


$$
\begin{aligned}
& f=\bar{w}_{1} f_{1}+\bar{w}_{2} f_{2} \\
& f=\bar{w}_{1}\left(p_{1} x+q_{1} y+r_{1}\right)+\bar{w}_{2}\left(p_{2} x+q_{2} y+r_{2}\right) \\
& f=\left(\bar{w}_{1} x\right) p_{1}+\left(\bar{w}_{1} y\right) q_{1}+\left(\bar{w}_{1}\right) r_{1}+\left(\bar{w}_{2} x\right) p_{2}+\left(\bar{w}_{2} y\right) q_{2}+\left(\bar{w}_{2}\right) r_{2}
\end{aligned}
$$

Untuk $N$ data training dapat dibentuk menjadi sistem persamaan linear.

$$
\begin{aligned}
& \left(\bar{w}_{1} x\right)_{1} p_{1}+\left(\bar{w}_{1} y\right)_{1} q_{1}+\left(\bar{w}_{1}\right)_{1} r_{1}+\left(\bar{w}_{2} x\right)_{1} p_{2}+\left(\bar{w}_{2} y\right)_{1} q_{2}+\left(\bar{w}_{2}\right)_{1} r_{2}=f_{1} \\
& \left(\bar{w}_{1} x\right)_{2} p_{1}+\left(\bar{w}_{1} y\right)_{2} q_{1}+\left(\bar{w}_{1}\right)_{2} r_{1}+\left(\bar{w}_{2} x\right)_{2} p_{2}+\left(\bar{w}_{2} y\right)_{2} q_{2}+\left(\bar{w}_{2}\right)_{2} r_{2}=f_{2} \\
& \vdots \\
& \left(\bar{w}_{1} x\right)_{N} p_{1}+\left(\bar{w}_{1} y\right)_{N} q_{1}+\left(\bar{w}_{1}\right)_{N} r_{1}+\left(\bar{w}_{2} x\right)_{N} p_{2}+\left(\bar{w}_{2} y\right)_{N} q_{2}+\left(\bar{w}_{2}\right)_{N} r_{2}=f_{N}
\end{aligned}
$$

Bentuk sistem persamaan linear dapat dibuat menjadi bentuk matriks $A \theta=Y$ :

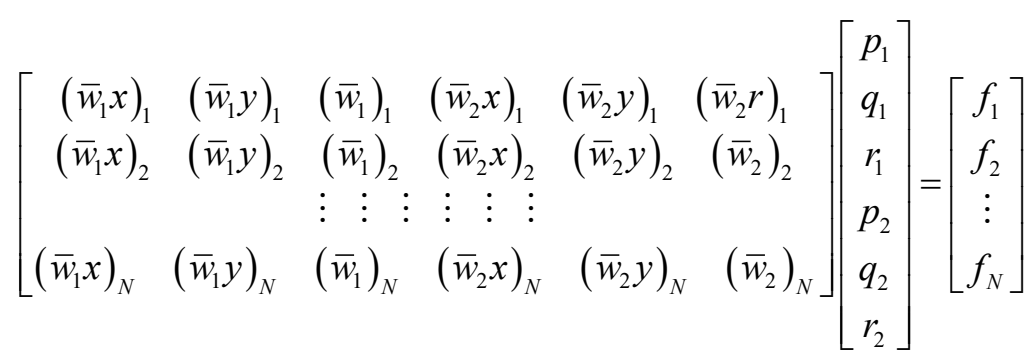

Sehingga matriks $\theta=\left[\begin{array}{llllll}p_{1} & q_{1} & r_{1} & p_{2} & q_{2} & r_{2}\end{array}\right]^{T}$ dapat dihitung menggunakan LSE :

$$
\theta=\left(A^{T} A\right)^{-1} A^{T} Y
$$

\section{c. Perhitungan Root of Mean Square Error (RMSE)}

Setelah iterasi satu epoch dilakukan, dilakukan perhitungan nilai Root of Mean Square Error (RMSE) sebagai berikut:

$$
R M S E=\sqrt{\frac{1}{p} \sum_{d=1}^{p} \frac{1}{m} \sum_{k=1}^{m}\left(T_{d k}-Y_{d k}\right)^{2}}
$$


dengan $T_{d k}$ adalah nilai target dan $Y_{d k}$ adalah hasil keluaran di unit output.

\section{METODOLOGI}

Pada penelitian ini, berdasarkan hasil korelasi, tiga dataset yang berbeda akan digunakan, yaitu dataset 1 , dataset 2, dan dataset 3. Dataset 1 terdiri dari input yaitu kelembaban udara pada jam ke $t$ dan kelembaban udara pada jam ke $t+1$, sedangkan output adalah kelembaban udara pada jam ke $t+2$. Konstruksi dataset 1 dapat dibentuk pada Gambar 2 .

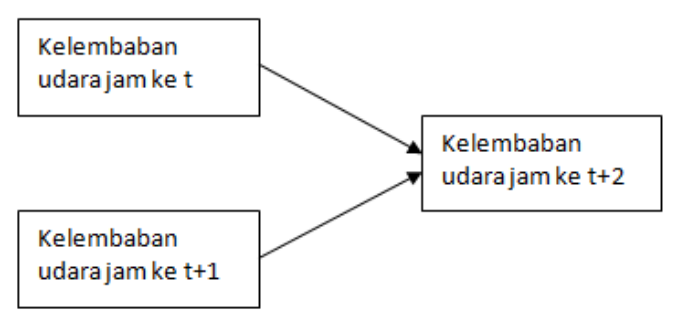

Gambar 2. Input dan Output pada Dataset 1

Dataset 2 terdiri dari input yaitu kelembaban udara pada hari ke $t$ dan kelembaban udara pada hari ke $t+1$, sedangkan output adalah kelembaban udara pada hari ke $t+2$. Konstruksi dataset 2 dapat dibentuk pada Gambar 3.

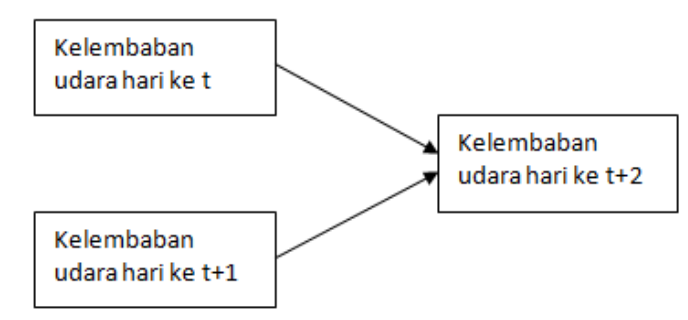

Gambar 3. Input dan Output pada Dataset 2

Dataset 3 terdiri dari input yaitu kelembaban udara pada hari ke $t$ dan kelembaban udara pada hari ke $t+3$, sedangkan output adalah kelembaban udara pada hari ke $t+6$. Konstruksi dataset 3 dapat dibentuk pada Gambar 4.

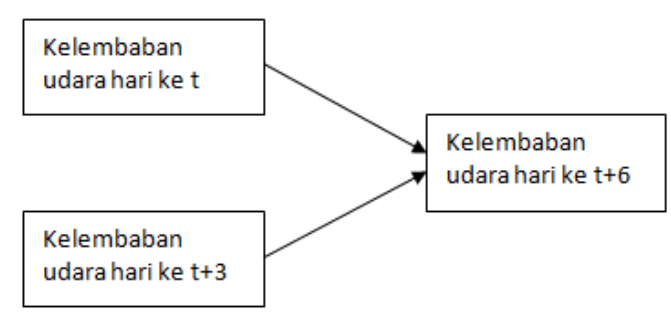

Gambar 4. Input dan Output pada Dataset 3 


\section{HASIL DAN PEMBAHASAN}

Data yang dipakai dalam penelitian ini adalah data kelembaban udara (\%) di Jakarta selama bulan Januari-Juli 2012 dengan jumlah 200 data. Dari data tersebut akan dihitung korelasi data antara input dan ouput dan dilakukan simulasi menggunakan ANFIS. Parameter ANFIS yang digunakan dapat dilihat pada Tabel 1.

Tabel 1. Parameter pada ANFIS

\begin{tabular}{|c|c|c|}
\hline No & Parameter & Jumlah \\
\hline 1 & Maksimum epoch & 30 \\
\hline 2 & Jumlah fungsi keanggotaan (generalized bell) & $\begin{array}{c}2 \text { (input 1), } \\
2 \text { (input 2) }\end{array}$ \\
\hline 3 & Jumlah aturan fuzzy & $2 \times 2=4$ \\
\hline 4 & Jumlah consequent parameter (linear parameter) & $3 \times 4=12$ \\
\hline 5 & Jumlah premise parameter (non linear parameter) & $3 \times 4=12$ \\
\hline
\end{tabular}

Sebelum simulasi ANFIS diterapkan, partisi data menjadi data training sebesar $80 \%$ dan data testing sebesar 20\%. Dari 200 data, data yang digunakan pada data testing adalah data kelipatan 5 , yaitu data $5,10,15, \ldots, 200$ sehingga diperoleh data sebanyak 40 , sedangkan data yang digunakan pada data training adalah data bukan kelipatan 5 sehingga diperoleh data sebanyak 160.

\subsection{Hasil Korelasi Data}

Hasil korelasi data pada dataset 1 ditunjukkan pada Gambar 5(a) dan Gambar 5(b) serta Tabel 2 adalah perhitungan nilai korelasi menggunakan persamaan (1). Gambar 5(a) adalah grafik korelasi kelembaban udara pada jam ke $t$ sebagai variabel $x$ dengan kelembaban udara pada jam ke $t+2$ sebagai variabel $y$. Gambar 5(b) adalah grafik korelasi kelembaban udara pada jam ke $t+1$ sebagai variabel $x$ dengan kelembaban udara pada jam ke $t+2$ sebagai variabel $y$.

Tabel 2. Hasil Korelasi Dataset 1

\begin{tabular}{|c|c|c|}
\hline Variabel $x$ & Variabel $y$ & Nilai Korelasi \\
\hline $\begin{array}{c}\text { Kelembaban udara pada } \\
\text { jam ke } \mathrm{t}\end{array}$ & $\begin{array}{c}\text { Kelembaban udara pada } \\
\text { jam ke } \mathrm{t}+2\end{array}$ & 0,751 \\
\hline $\begin{array}{c}\text { Kelembaban udara pada } \\
\text { jam ke } \mathrm{t}+1\end{array}$ & $\begin{array}{c}\text { Kelembaban udara pada } \\
\text { jam ke } \mathrm{t}+2\end{array}$ \\
\hline
\end{tabular}




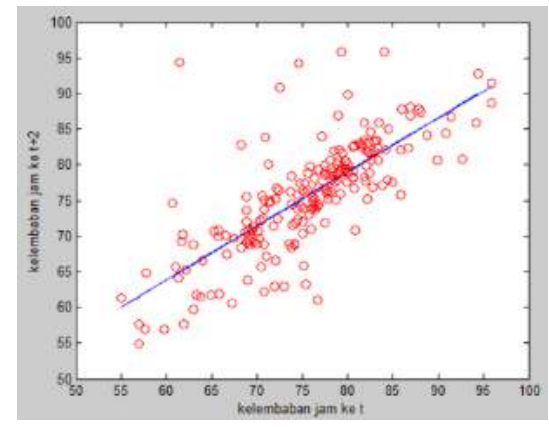

(a)

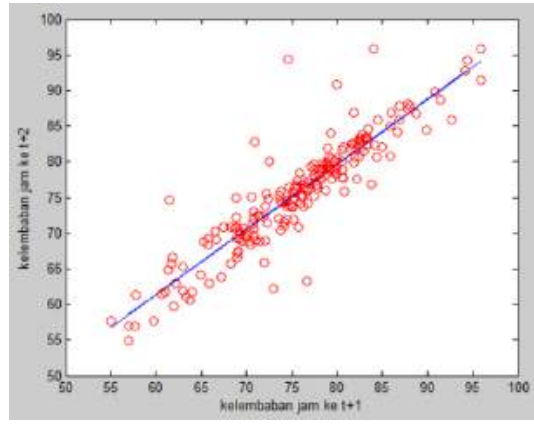

(b)

Gambar 5. Korelasi pada Dataset 1.

Hasil korelasi data pada dataset 2 ditunjukkan pada Gambar 6(a) dan Gambar 6(b) serta Tabel 3 adalah perhitungan nilai korelasi menggunakan persamaan (1). Gambar 6(a) adalah grafik korelasi kelembaban udara pada hari ke $t$ sebagai variabel $x$ dengan kelembaban udara pada hari ke $t+2$ sebagai variabel $y$. Gambar 6(b) adalah grafik korelasi kelembaban udara pada hari ke $t+1$ sebagai variabel $x$ dengan kelembaban udara pada hari ke $t+2$ sebagai variabel $y$.

Tabel 3. Hasil Korelasi Dataset 2

\begin{tabular}{|c|c|c|}
\hline Variabel $x$ & Variabel $y$ & Nilai Korelasi \\
\hline $\begin{array}{c}\text { Kelembaban udara pada } \\
\text { hari ke } \mathrm{t}\end{array}$ & $\begin{array}{c}\text { Kelembaban udara pada } \\
\text { hari ke } \mathrm{t}+2\end{array}$ & 0,416 \\
\hline $\begin{array}{c}\text { Kelembaban udara pada } \\
\text { hari ke } \mathrm{t}+1\end{array}$ & $\begin{array}{c}\text { Kelembaban udara pada } \\
\text { hari ke } \mathrm{t}+2\end{array}$ \\
\hline
\end{tabular}

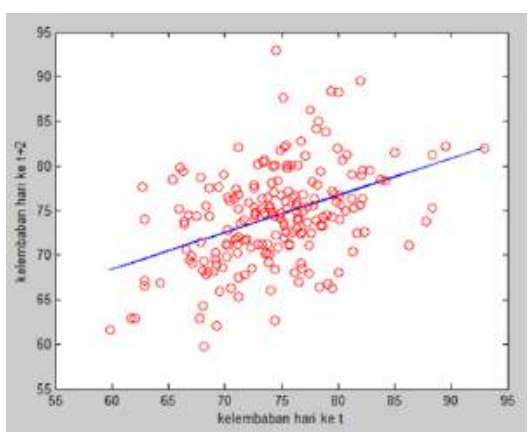

(a)

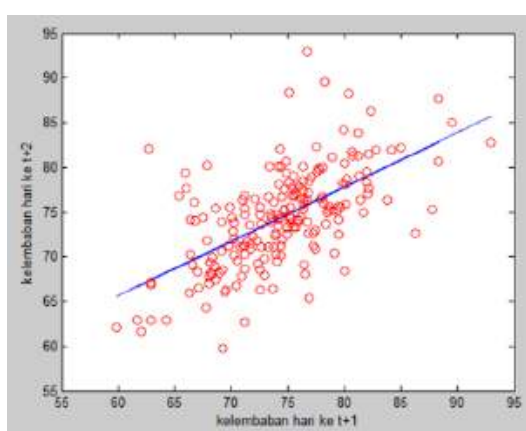

(b)

Gambar 6. Korelasi pada Dataset 2. 
Hasil korelasi data pada dataset 3 ditunjukkan pada Gambar 7(a) dan Gambar 7(b) serta Tabel 3 adalah perhitungan nilai korelasi menggunakan persamaan (1). Gambar 7(a) adalah grafik korelasi kelembaban udara pada hari ke $t$ sebagai variabel $x$ dengan kelembaban udara pada hari ke $t+6$ sebagai variabel $y$. Gambar 7(b) adalah grafik korelasi kelembaban udara pada hari ke $t+3$ sebagai variabel $x$ dengan kelembaban udara pada hari ke $t+6$ sebagai variabel $y$.

Tabel 4. Hasil Korelasi Dataset 3

\begin{tabular}{|c|c|c|}
\hline Variabel $x$ & Variabel $y$ & Nilai Korelasi \\
\hline $\begin{array}{c}\text { Kelembaban udara pada } \\
\text { hari ke } \mathrm{t}\end{array}$ & $\begin{array}{c}\text { Kelembaban udara pada } \\
\text { hari ke } \mathrm{t}+6\end{array}$ & 0,136 \\
\hline $\begin{array}{c}\text { Kelembaban udara pada } \\
\text { hari ke } \mathrm{t}+3\end{array}$ & $\begin{array}{c}\text { Kelembaban udara pada } \\
\text { hari ke } \mathrm{t}+6\end{array}$ \\
\hline
\end{tabular}

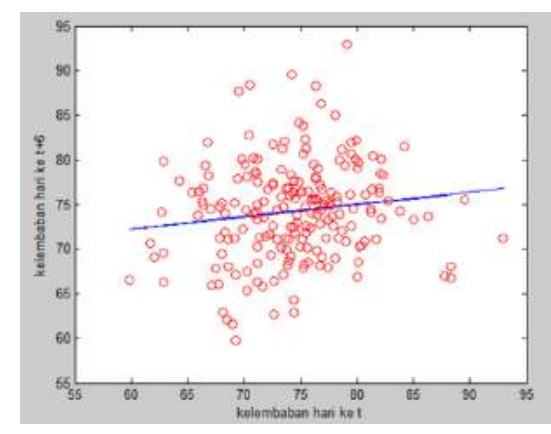

(a)

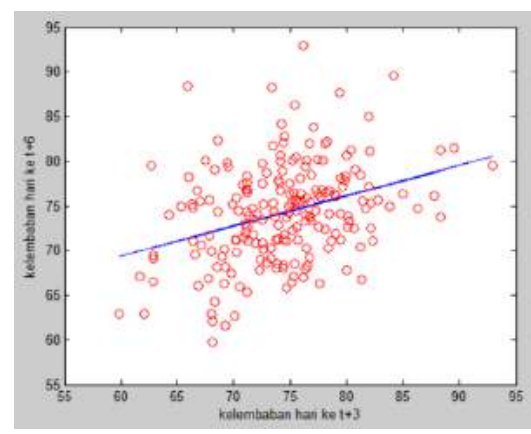

(b)

Gambar 7. Korelasi pada Dataset 3.

\subsection{Simulasi ANFIS pada Dataset 1}

Dari hasil korelasi data pada dataset 1 , kelembaban udara pada jam ke $t+2$ dipengaruhi oleh kelembaban udara pada jam ke $t$ dan jam ke $t+1$. Ketika proses optimisasi ANFIS diterapkan, proses konvergensi pada nilai Root of Mean Square Error (RMSE) data training dapat dilihat pada Gambar 8 dan menghasilkan nilai RMSE data training 2,557 dan nilai RMSE data testing 3,637.

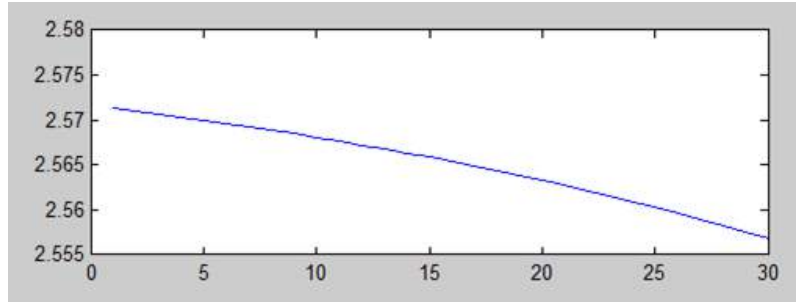

Gambar 8. Proses Konvergensi Root of Mean Square Error (RMSE) dari Data Training

Premise parameter optimal akan menghasilkan fungsi keanggotaan (generalized bell) optimal seperti pada Gambar 9. Gambar 9 (atas) adalah fungsi keanggotaan optimal pada input 1, yaitu 
kelembaban udara pada jam ke $t$ sedangkan Gambar 9 (bawah) adalah fungsi keanggotaan optimal pada input 2, yaitu kelembaban udara pada jam ke $t+1$.

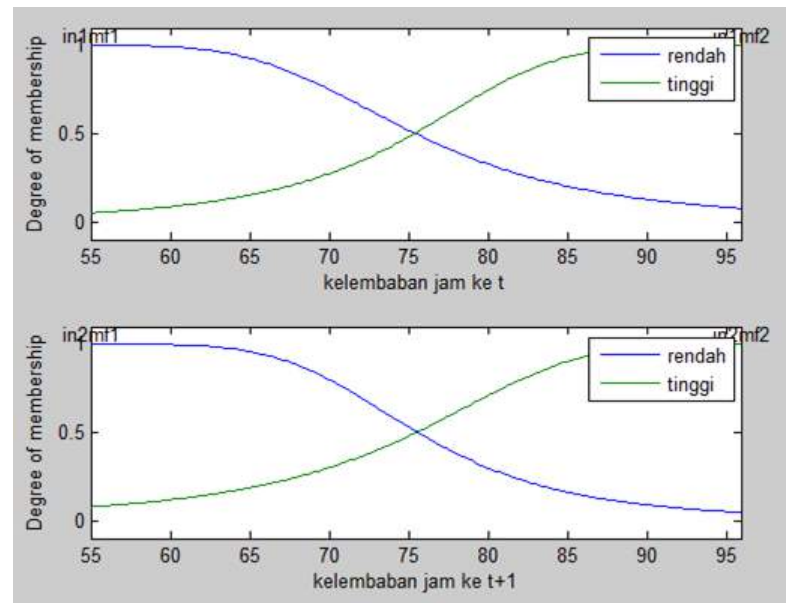

Gambar 9. Hasil Optimisasi pada Fungsi Keanggotaan Kelembaban pada Jam ke t (Atas), Kelembaban pada Jam ke t+1 (Bawah)

Hasil peramalan antara nilai target dengan output dapat dilihat pada Gambar 10. Gambar 10 (atas) adalah hasil peramalan antara nilai target dengan output pada data testing sebanyak 40 data. Gambar 10 (bawah) adalah hasil peramalan antara nilai target dengan output pada data training sebanyak 160 data.

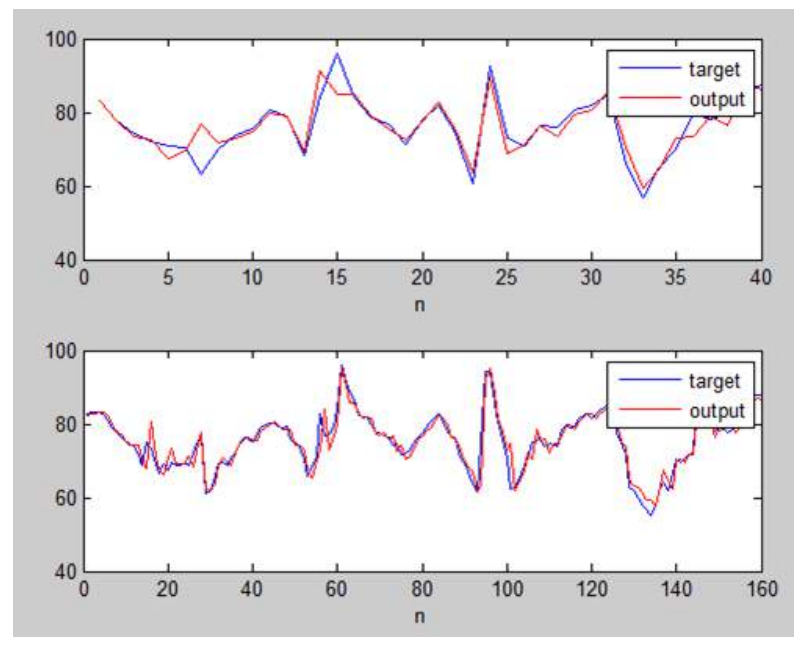

Gambar 10. Perbandingan Nilai Target dan Output pada Data Testing (Atas) dan Data Training (Bawah)

\subsection{Simulasi ANFIS pada Dataset 2}

Dari hasil korelasi data pada dataset 2, kelembaban udara pada hari ke $t+2$ dipengaruhi oleh kelembaban udara pada hari ke $t$ dan hari ke $t+1$. Ketika proses optimisasi ANFIS diterapkan, proses konvergensi pada nilai Root of Mean Square Error (RMSE) data training dapat dilihat pada Gambar 11 dan menghasilkan nilai RMSE data training 4,233 dan nilai RMSE data testing 4,297. 


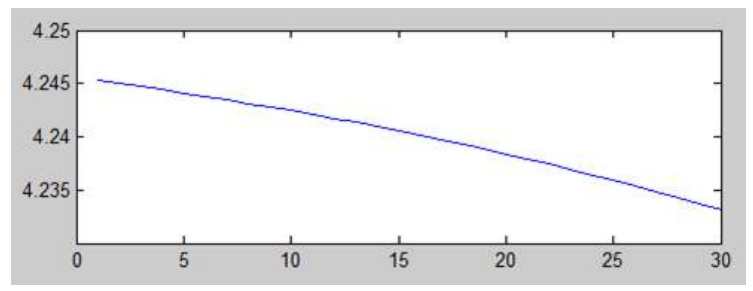

Gambar 11. Proses Konvergensi Root of Mean Square Error (RMSE) dari Data Training

Premise parameter optimal akan menghasilkan fungsi keanggotaan (generalized bell) optimal seperti pada Gambar 12. Gambar 12 (atas) adalah fungsi keanggotaan optimal pada input 1, yaitu kelembaban udara pada hari ke $t$ sedangkan Gambar 12 (bawah) adalah fungsi keanggotaan optimal pada input 2, yaitu kelembaban udara pada hari ke $t+1$.

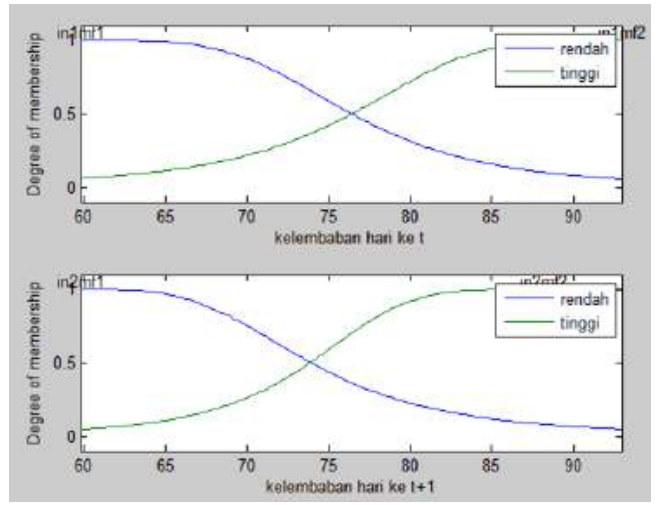

Gambar 12. Hasil Optimisasi pada Fungsi Keanggotaan Kelembaban pada Hari ke t (Atas), Kelembaban pada Hari ke $\mathrm{t}+1$ (Bawah)

Hasil peramalan antara nilai target dengan output dapat dilihat pada Gambar 13. Gambar 13 (atas) adalah hasil peramalan antara nilai target dengan output pada data testing sebanyak 40 data. Gambar 13 (bawah) adalah hasil peramalan antara nilai target dengan output pada data training sebanyak 160 data.

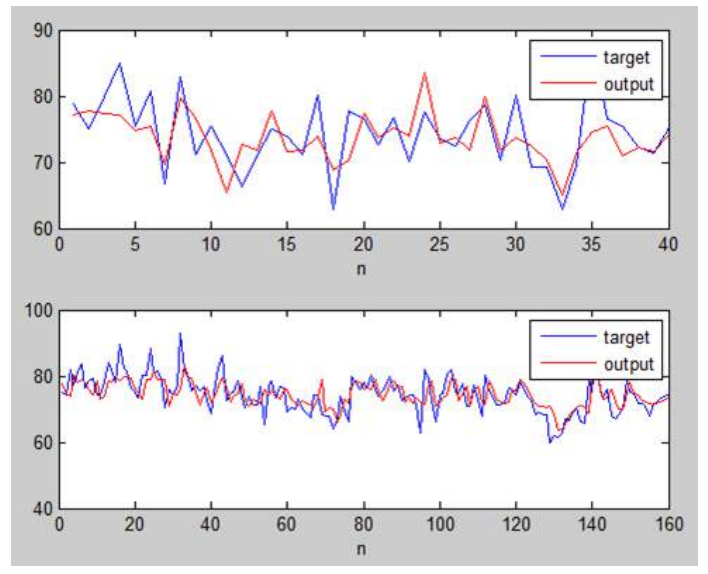

Gambar 13. Perbandingan Nilai Target dan Output pada Data Testing (Atas) dan Data Training (Bawah) 


\subsection{Simulasi ANFIS pada Dataset 3}

Dari hasil korelasi data pada dataset 3, kelembaban udara pada hari ke $t+6$ dipengaruhi oleh kelembaban udara pada hari ke $t$ dan hari ke $t+3$. Ketika proses optimisasi ANFIS diterapkan, proses konvergensi pada nilai Root of Mean Square Error (RMSE) data training dapat dilihat pada Gambar 14 dan menghasilkan nilai RMSE data training 4,987 dan nilai RMSE data testing 5,699.

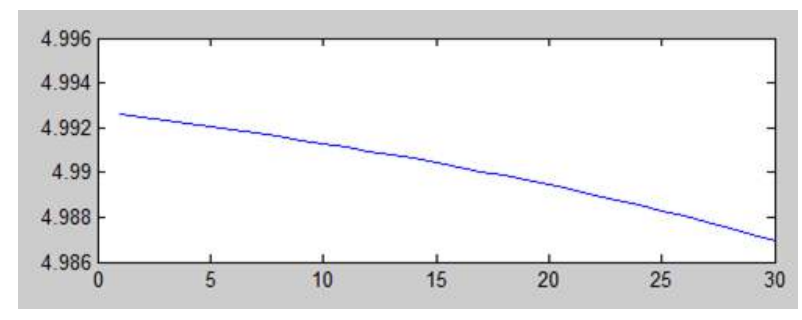

Gambar 14. Proses Konvergensi Root of Mean Square Error (RMSE) dari Data Training

Premise parameter optimal akan menghasilkan fungsi keanggotaan (generalized bell) optimal seperti pada Gambar 15. Gambar 15 (atas) adalah fungsi keanggotaan optimal pada input 1, yaitu kelembaban udara pada hari ke $t$ sedangkan Gambar 15 (bawah) adalah fungsi keanggotaan optimal pada input 2, yaitu kelembaban udara pada hari ke $t+3$.

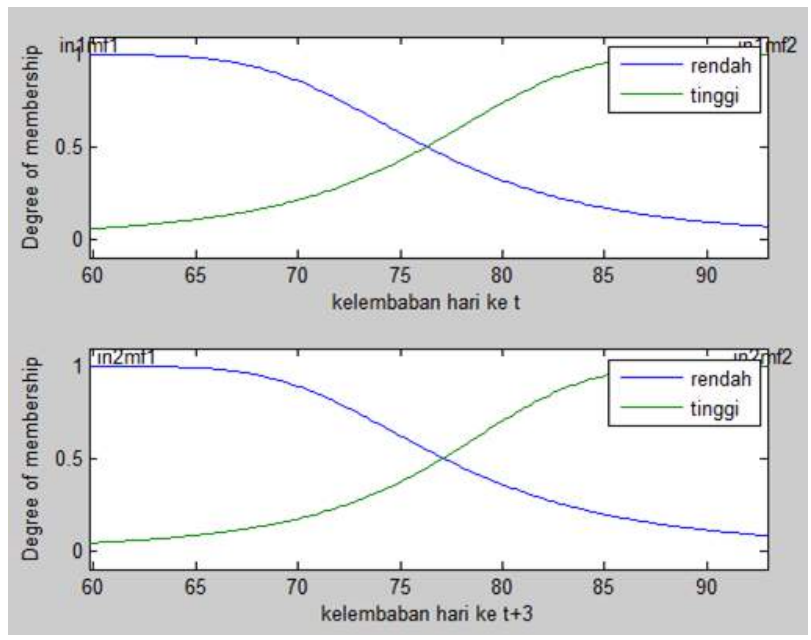

Gambar 15. Hasil Optimisasi pada Fungsi Keanggotaan Kelembaban pada Hari ke t (Atas), Kelembaban pada Hari ke t+3 (Bawah)

Hasil peramalan antara nilai target dengan output dapat dilihat pada Gambar 16. Gambar 16 (atas) adalah hasil peramalan antara nilai target dengan output pada data testing sebanyak 40 data. Gambar 16 (bawah) adalah hasil peramalan antara nilai target dengan output pada data training sebanyak 160 data. 


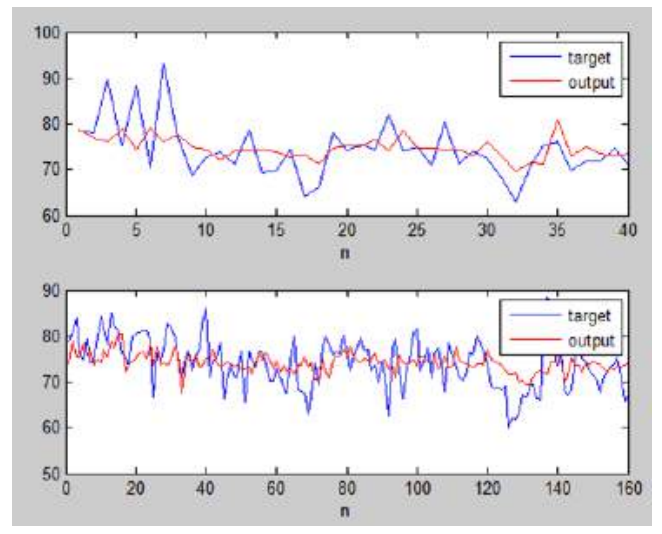

Gambar 16. Perbandingan Nilai Target dan Output pada Data Testing (Atas) dan Data Training (Bawah)

\section{KESIMPULAN}

ANFIS menggunakan metode hybrid dalam perhitungan. Terdapat dua bagian dari metode hybrid yaitu alur maju dan alur mundur. Pada alur maju, sinyal bergerak maju sampai layer 4 dan consequent parameter dihitung dengan Least Square Estimator (LSE). Pada alur mundur, laju error bergerak mundur dan premise parameter diupdate dengan penurunan gradient (gradient descent). Nilai korelasi antara input dan output memberikan pengaruh pada hasil peramalan menggunakan ANFIS. Simulasi dilakukan pada tiga dataset dengan struktur yang berbeda berdasarkan nilai korelasi. Berdasarkan hasil simulasi, hasil peramalan tergantung pada nilai korelasi. Semakin kuat nilai korelasi yaitu korelasi mendekati satu, memberikan hasil peramalan yang lebih optimal yang dapat dilihat dengan nilai RMSE yang kecil.

\section{UCAPAN TERIMA KASIH}

Terima kasih disampaikan kepada Kementrian Riset Teknologi dan Pendidikan Tinggi atas dana Penelitian Dosen Pemula tahun 2019.

\section{DAFTAR PUSTAKA}

[1] Han, J., Kamber, M., Pei, J. Data Mining Concepts and Techniques, Elsevier, USA. 2012

[2] Herlambang, T., Mufarrikoh, Z., Karya, D.F, Rahmalia, D. Estimation of Water Level and Steam Temperature Using Ensemble Kalman Filter Square Root (EnKF-SR), Journal of Physics : Conference Series, Vol 1008, No. 1. 2018.

[3] Herlambang, T., Rasyid, R.A., Hartatik, S., Rahmalia, D. Estimasi Posisi Mobile Robot Menggunakan Metode Akar Kuadrat Unscented Kalman Filter (AK-UKF), Technology Science and Engineering Journal, Vol 1, No.2. 2017.

[4] Rahmalia, D., Herlambang, T. Application Kohonen Network and Fuzzy C Means for Clustering Airports Based on Frequency of Flight, Kinetik: Game Technology, Information System, Computer Network, Computing, Vol. 3, No. 3, pp. 229-236. 2018.

[5] Rahmalia, D., Aini, N. Pengaruh Korelasi Data pada Peramalan Suhu Udara Menggunakan Backpropagation Neural Network, Zeta-Math Journal,Vol 4, No.1, pp. 1-6. 2018.

[6] Rahmalia, D., Herlambang, T. "Prediksi Cuaca Menggunakan Algoritma Particle Swarm Optimization-Neural Network (PSONN)", Seminar Nasional Matematika dan Aplikasinya Universitas Airlangga, Surabaya. 2017.

[7] Rahmalia, D. Estimation of Exponential Smoothing Parameter on Pesticide Characteristic Forecast Using Ant Colony Optimization (ACO), Eksakta : Jurnal Ilmu-ilmu MIPA, Vol 18, No.1, pp. 56-63. 2018. 
[8] Rahmalia, D., Pradana, M.S. Backpropagation Neural Network pada Data yang tak Stasioner (Studi Kasus: Jumlah Penderita Penyakit Ebola), Jurnal Riset dan Aplikasi Matematika (JRAM), Vol 3, No.1, pp. 32-42. 2019.

[9] Shing, J., Jang, R. ANFIS : Adaptive Network Based Fuzzy Inference System, IEEE Transaction on System, Man and Cybernetics, Vol 23, No. 3, pp. 665-685.1993.

[10] Suparta, W., Alhasa, K.M. Modelling of Tropospheric Delays Using ANFIS, SpringerBriefs in Meteorology. 2016.

[11] Walpole, R.E., Myers, R.H., Myers, S.L. Probability \& Statistics for Engineers \& Scientists, Prentice Hall, USA. 2012. 